Update Article

\title{
Designs for research of High Dilutons in animal models: an update
}

\author{
Adrian Alecu, Mariana Alecu, Romeo Brezeanu, \\ Gabriela Mărcuș, Adriana Cojocaru. \\ University of Medicine and Pharmacy, Târgu-Mureș, Romania
}

\begin{abstract}
This article discusses the series of tests on animal experimental models carried out by our group to evaluate the effect of homeopathic preparations selected according to traditional criteria of pathogenetic similarity. Our overall experience indicates that it is not difficult to carry out experimental studies assaying homeopathic medicines in randomized placebo-controlled tests returning statistically analyzable results. The basic requirement for this purpose is to select validated experimental models. The simplest and most reliable ones are the ones arising from common daily clinical practice or those taken from classical pharmacological studies modified as to fit the goals of a homeopathic assay. By proceeding in this way it will be possible to build a sound body of evidence for the biological effects of high dilutions.
\end{abstract}

Keywords: High dilutions, Experimental models, Pathogenetic similarity, Placebo-controlled, Statistical significance.

\section{Introduction}

Our research group has been working since 2004 in testing the effects of homeopathic preparations on animal models strictly selected according pathogenetic criteria of similarity. In particular, our line of research seeks to establish the actual effects of such agents by comparison to conventional drugs and mainly to placebo in order to verify or refute the hypothesis stating that high dilutions merely produce placebo effects. [1, 2]

The aim of the actual paper is to present a summary of our research activity and results in order to make some theoretical and methodological reflections that can contribute to the development of better methods to explore high dilutions.

\section{Tests design}

All our tests were carried out on laboratory rats and mice made available by the University of Medicine and Pharmacy of Târgu-Mureş, România. Various diseases were experimentally induced, followed by treatment homeopathic, conventional or combined - controlled against placebo.

In all our experiments we use homogeneous experimental populations, composed by male animals divided into groups with equal number of animals, usually between 10 and 15 per group. Each group was randomly assigned to treatment groups or placebo and particular care was devoted to ensure that no significant differences were present among the experimental populations at the onset of the tests.

It must be emphasized that all our experiments strictly comply with European Convention for the Protection of Vertebrate Animals used for Experimental and Other Scientific Purposes [3]. 
The complexity of the designs varied according the established goals. The simplest experimental setting aimed at verifying the putative property of Arnica montana in homeopathic preparation to heal wounds. For this purpose, we produced mechanical trauma in mice and then treated one group with Arnica montana $7 \mathrm{cH}$ and another group with placebo [4].

On the other hand, a more complex design aimed at verifying the putative anti-inflammatory effects of Apis mellifica $7 \mathrm{cH}$ and $15 \mathrm{cH}$ by comparison to placebo and then to compare this effects against steroidal (SAID) and non-steroidal (NSAID) anti-inflammatory drugs, respectively hydrocortisone hemissucinate and diclofenac, as well as a combination of the homeopathic and conventional medicine [5]. Local inflammation was produced at the posterior limbs of mice by injecting formaldehyde, the animals were then divided into the different treatments and placebo groups.

Aqueous solutions were prepared by dissolving 1 sugar homeopathic globule (4 mm diameter) in $1 \mathrm{ml}$ of plain water; placebo solutions were similarly prepared from plain sugar globules not impregnated with homeopathic medicines. In some experiments the solutions were given through a gastric tube; later on we attempted at giving the solutions p.o. by pouring drops of the solutions directly in the animals' mouth so that the animals took voluntarily the solution, a procedure that presented no problems of compliance (figure 1).

In most cases, treatments were given as immediately as possible after the induction of the experimental disease, as our protocols consider the variable time an important parameter of evaluation. As primary outcomes, we selected definite objectively measurable parameters, such as the time for complete healing of a wound or the evolution of the dorsoplantar diameter in models including experimental induction

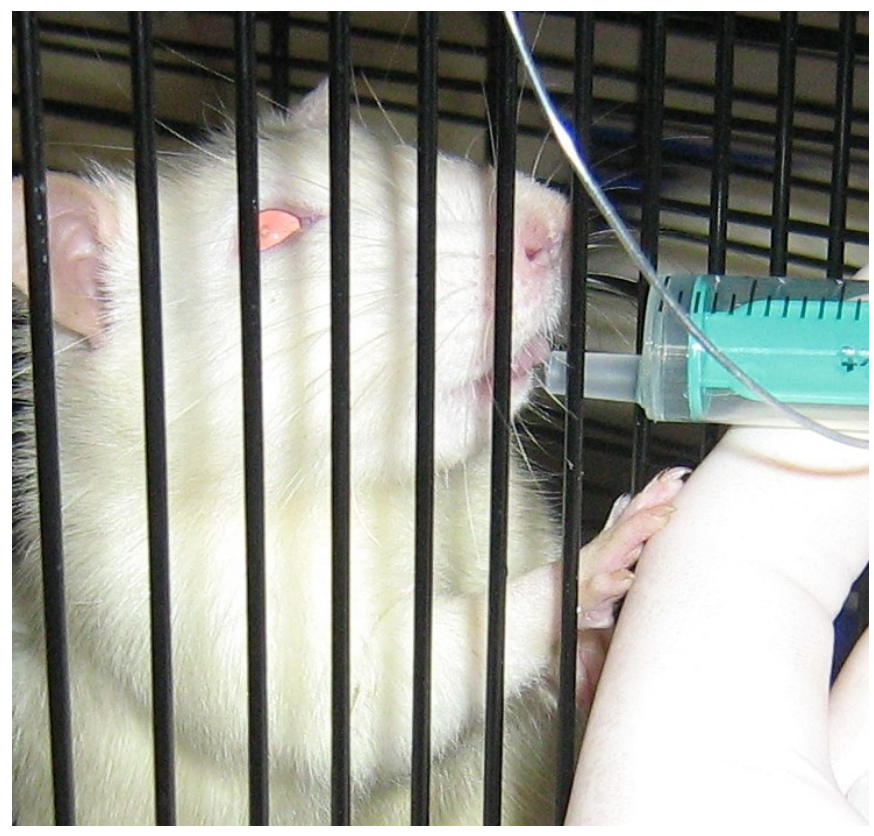

Figure 1: drops of the solutions directly in the animals' mouth of swelling. Measurements were carried out daily and recorded them in tables and worksheets for later statistical analysis.

\section{Analysis of results}

Most statistical data were processed with Graphpad InStat ${ }^{\circledR} 3.06$ or Microsoft Excel ${ }^{\circledR}$. According to the set of data, the statistical tests used were various. In order to decide if a certain group presents a gaussian distribution of events we used the Kolmogorov-Smirnov test or "normality" test. The Grubbs test for outliers is used in order to exclude the aberrant values from the collected data. Fischer test or Chi-square test were used to compare means or percentage values. The T-test was used to determine the statistical significance between two series of data in conjunction with the $\mathrm{F}$-test to compare the variances and to choose the type of t-test. The nonparametric Mann-Whitney test was used instead of t-test when the distribution of data was not gaussian. In our series, we considered statistically significant tests returning $p$ value less than 0.05 .

\section{Experimental models}

1. Response of rats to homeopathic treatment after first-degree burns [6] 
To assess the effect of homeopathic treatment in first-degree burns, Whistar rats had their rear limbs immersed in hot water until the appearance of local edema and erythema (figure 2). The animals treated with Apis mellifica $9 \mathrm{cH}$ healed significantly faster (figure 3) than the ones treated with Belladona $9 \mathrm{cH}(\mathrm{p}<0.01$ ). On the other hand, both groups treated with homeopathic medicines healed significantly faster that the control group treated with placebo (Apis $\mathrm{p}<0.001$ and Belladona $\mathrm{p}<0.05$ ).

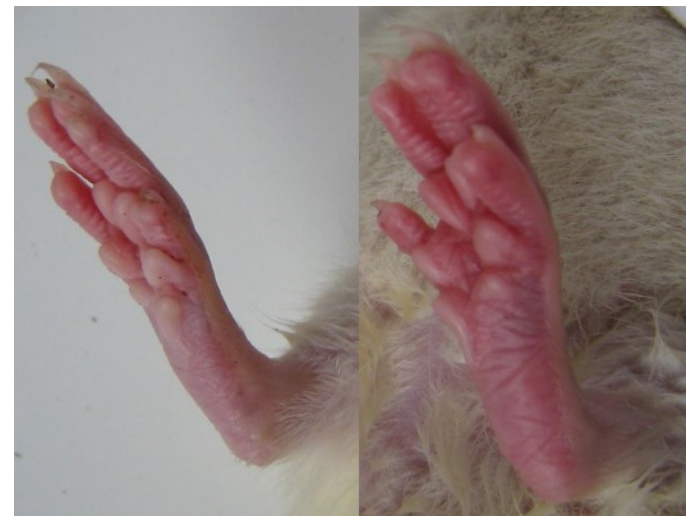

Figure 2: The difference between the limbs, healthy on the left picture and with $1^{\text {st }}$ degree burn on the right picture.

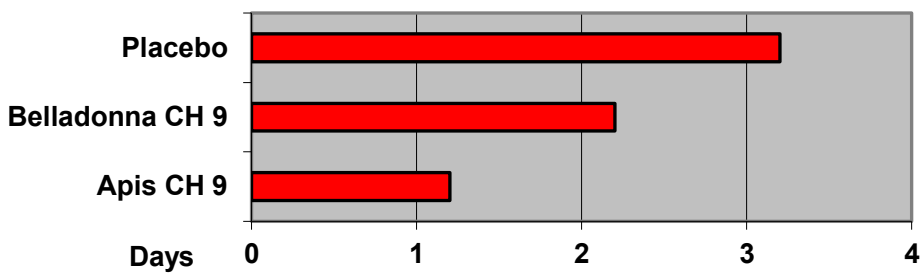

Figure 3: Average number of days until the healing of the burns for each group

\section{Effect of the homeopathic remedy Arnica montana $7 \mathrm{cH}$ on mechanical trauma in mice [4]}

The effects of Arnica montana on trauma had been long acknowledged, including its homeopathic preparations. Whereas controlled clinical trials produced controversial results, this experimental study on animals evaluated the effect of Arnica montana $7 \mathrm{cH}$ on swelling, pain and mobilization of limbs with experimentally induced mechanical trauma in mice (figure 4).
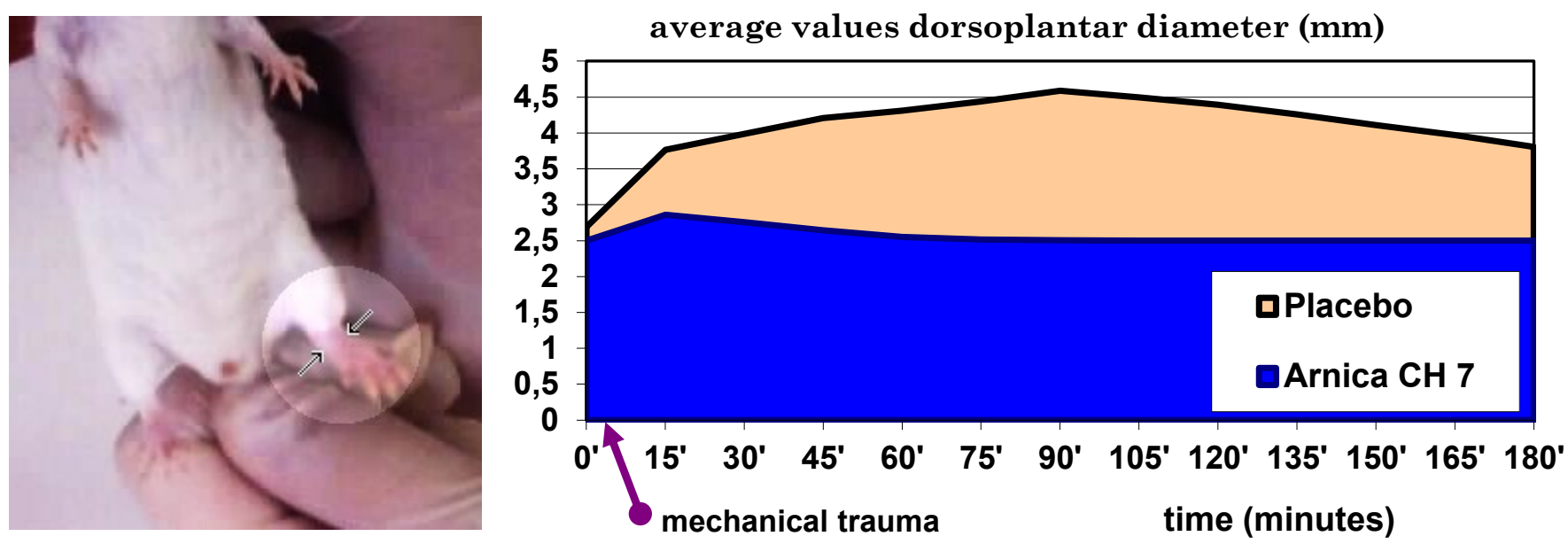

Figure 4: Experimentally induced mechanical trauma in mice.

Results showed that the control group exhibited remarkable and persistent swelling significantly larger than in the group treated with the homeopathic remedy $(\mathrm{p}<0.0001)$. Swelling, lack of mobility and avoidance of motion persisted in the control group up to 180 minutes after the induction of trauma. In the group treated with Arnica montana $7 \mathrm{cH}$ swelling disappeared completely in up to 105 minutes $(\mathrm{p}<0.0001)$ and animals 
exhibited an overall good state and normal activity, with an ability to move the affected limb even when it was fractured.

\section{Effect of homeopathic medicines Arnica montana and Staphisagria on the time of healing of surgical wounds [7]}

This study sought to establish the effect of Arnica montana, an acknowledged remedy for trauma, on the time of healing of surgical wounds (figure 5). As also homeopathic remedy Staphisagria is used in surgical practice to accelerate the healing of wounds, it was also included in the experimental design. To further establish whether the effects would vary with dilutions below and above Avogadro's number, both remedies were tested in dilutions $7 \mathrm{cH}$ and $30 \mathrm{cH}$.

The results showed that the 4 groups that received homeopathic treatment exhibited significant $(p<0.0001)$ reduction of the number of days required for the full healing of the surgical wound (15-16 days) by comparison to the control (22-23 days). The difference between the groups treated with Arnica montana and Staphisagria was not significant, as neither was the difference between dilutions $7 \mathrm{cH}$ and $30 \mathrm{cH}$.

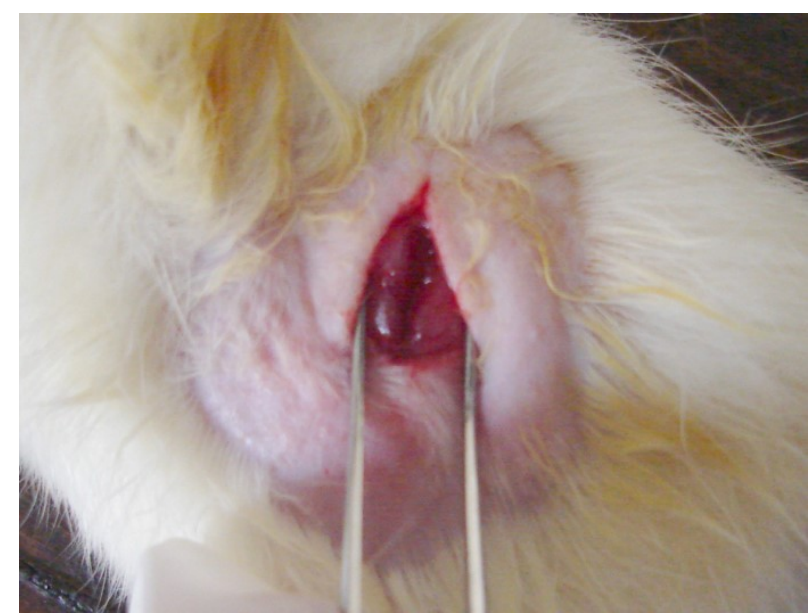

Figure 6: The incision.

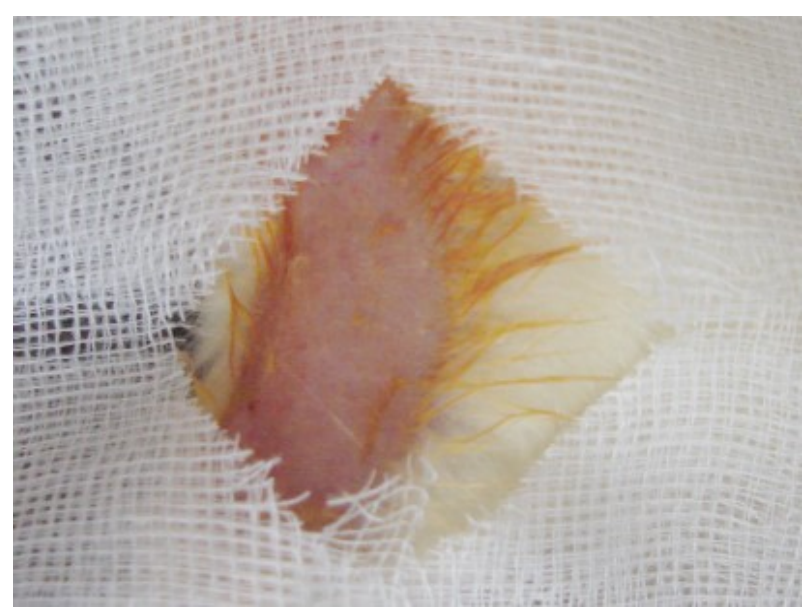

Figure 5: Surgery zone prepared by depilation and disinfection.

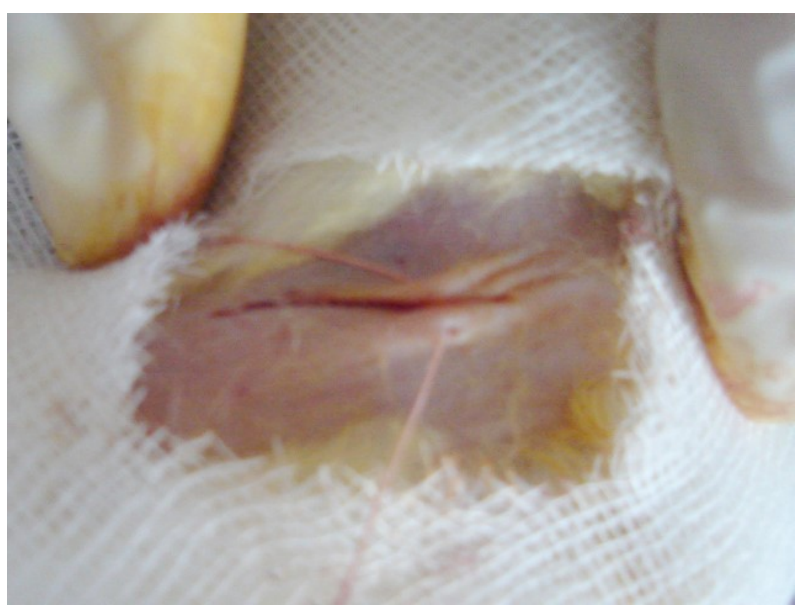

Figure 7: The suture.

A deep incision is performed on the external side of the thigh, following the line of the femur until the appearance of the bone (figure 6). The skin is sutured in 3 separate points with nonresorbable silk thread (figure 7). The evolution of the incision was assessed until the complete healing (figures 8 and 9, table 1). 

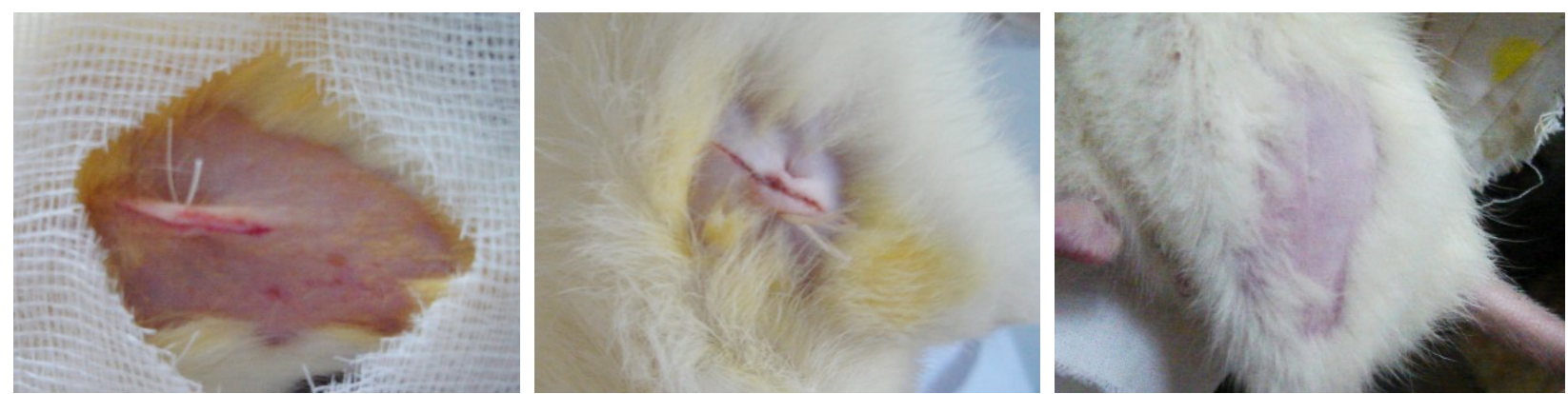

Figure 8: The evolution.

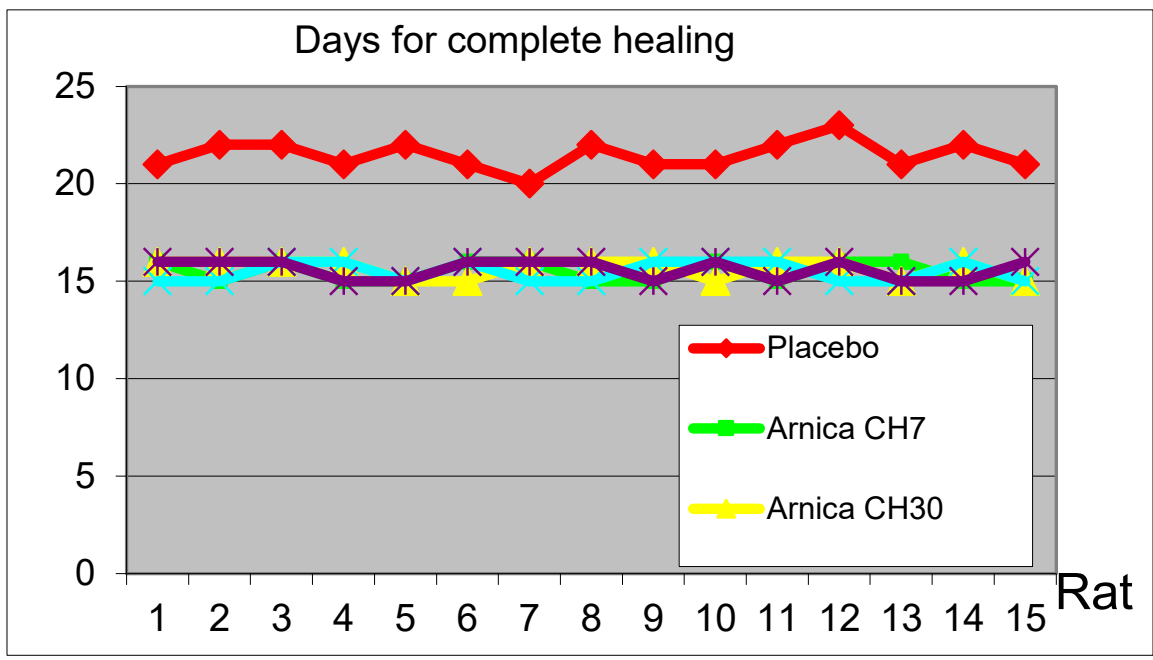

Figure 9 - Daily Evolution

Table 1 - the complete datasheet of the number of days that were necessary for the complete healing.

\begin{tabular}{|l|c|c|c|c|c|c|c|c|c|c|c|c|c|c|c|}
\hline & \multicolumn{10}{|c|}{ Group } & \multicolumn{10}{|c|}{ Days for complete healing } \\
\hline Placebo & 21 & 22 & 22 & 21 & 22 & 21 & 20 & 22 & 21 & 21 & 22 & 23 & 21 & 22 & 21 \\
\hline Arnica CH 7 & 16 & 15 & 16 & 15 & 15 & 16 & 16 & 15 & 15 & 16 & 15 & 16 & 16 & 15 & 15 \\
\hline Arnica CH 30 & 16 & 16 & 16 & 16 & 15 & 15 & 16 & 16 & 16 & 15 & 16 & 16 & 15 & 16 & 15 \\
\hline Staphysagria CH 7 & 15 & 15 & 16 & 16 & 15 & 16 & 15 & 15 & 16 & 16 & 16 & 15 & 15 & 16 & 15 \\
\hline Staphysagria CH 30 & 16 & 16 & 16 & 15 & 15 & 16 & 16 & 16 & 15 & 16 & 15 & 16 & 15 & 15 & 16 \\
\hline
\end{tabular}


4. Homeopathic remedy Belladona compensates the blockage of the muscarinic receptor produced by atropine in experimental animals [8]

Pilocarpine is an alkaloid with direct agonistic effect on the muscarinic receptor of the parasympathetic nervous system. On the salivary glands it produces hypersecretion, which is experimentally used to evaluate the stimulation of the muscarinic receptor. Atropine - an alkaloid of Atropa belladonna L. - has the opposite action, through competitive antagonism of the cholinergic receptor. The blockage of the latter has effects similar to the decrease of the parasympathetic tonus of the organism, and on the salivary glands produces a fall of secretion. This study sought to establish weather homeopathic remedy Belladona - prepared from Atropa belladonna L. - according to homeopathic principles antidotes the blocking effect of atropine on the muscarinic receptor, manifested by the ability of pilocarpine to provoke salivation (figure 10).

Results showed that pilocarpine, indeed, elicited a very abundant secretion of saliva (figure 11). The administration of atropine before pilocarpine impeded the hypersecretion of saliva, whereas the administration of Belladona $7 \mathrm{cH}$ after atropine and before pilocarpine induced again hypersecretion of saliva. The statistical difference was in all

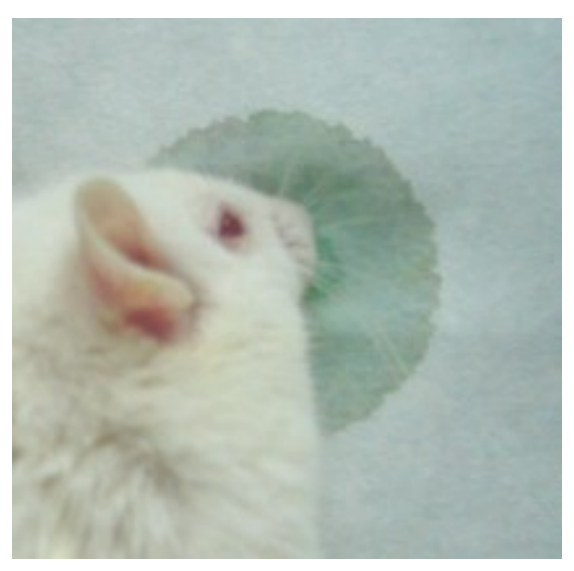

Figure 10 - Salivation. cases $\mathrm{p}<0.0001$.

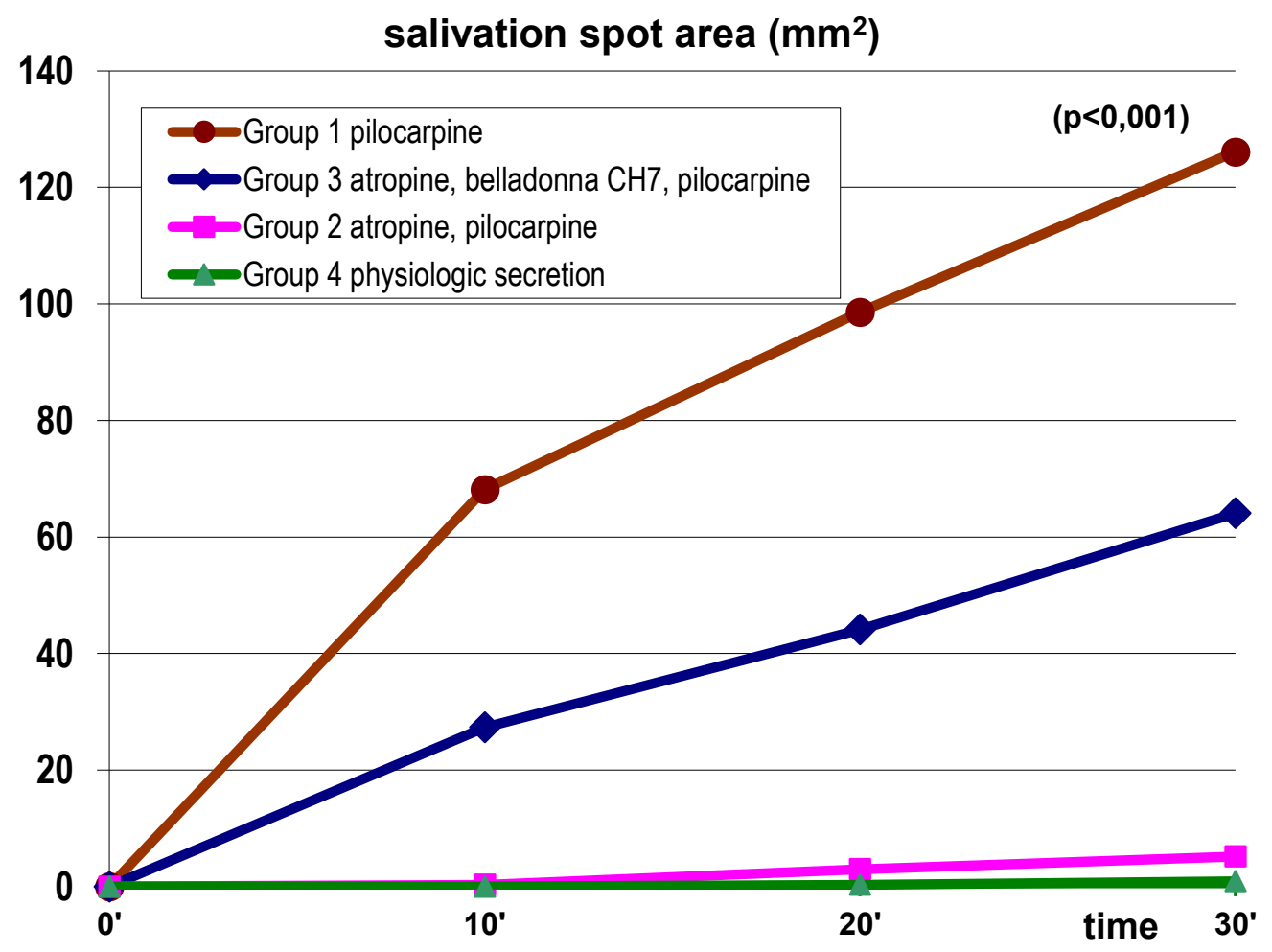

Figure 11 - Salivation spot area $\left(\mathrm{mm}^{2}\right)$ 


\section{Experimental research seeking to fight the manifestations of intoxication with strychnine through comparative homeopathic and allopathic treatments [9]}

This study sought to compare the effect of homeopathic remedy Nux vomica $7 \mathrm{cH}$ and diazepam on the symptoms of intoxication with strychnine in mice. The picture of the latter includes adynamia, tonic-clonic seizures, hypersensitiveness to sensorial stimuli, perceptual distortions, tachycardia, tachypnea, agitation and finally death. Seizures are due to glycine-mediated postsynaptic inhibition, strychnine acts as competitive antagonist and blocks the effect of glycine and the strycnine-sensitive glycine receptor Gly1. Diazepam is a benzodiazepine with sedative, myorelaxing and anticonvulsivant properties due to an action on the GABA receptor and is used in the treatment of seizures provoked by strychnine. Homeopathic remedy Nux vomica is prepared from the seeds of Strychnos nux vomica L., which have a high content in strychnine. Homeopathically, it is used in cases of seizures, aggravated by external stimuli, agitation and hypersensitiveness to stimuli - a picture very similar to the intoxication with strychnine (figure 12).

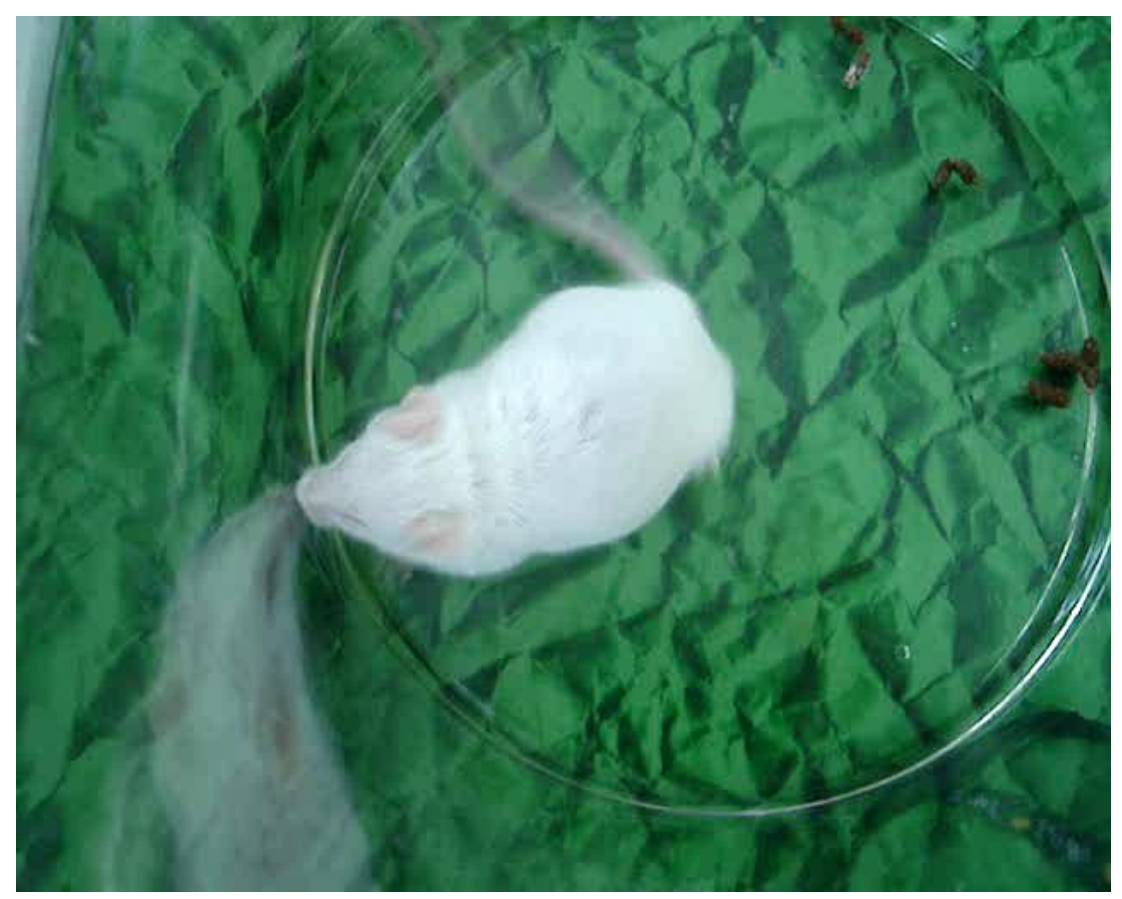

Figure 12 - The tail movement at the time of convulsion

In this study, three groups were subjected to experimental intoxication with strychnine. One group was treated with placebo (control), another one with diazepam and the third one with Nux vomica $7 \mathrm{cH}$ before the induction of intoxication. Variables evaluated were: time of appearance of seizures; number of animals that exhibited seizures; time until death; number of dead animals in each group (figures $13-16$ ).

The time for appearance of convulsions was significantly in the control group than in both groups treated $(p<0.0001)$; it was further significantly shorter $(\mathrm{p}<0.0001)$ in the group treated with diazepam than in the group treated with $\mathrm{Nux}$ vomica $7 \mathrm{cH}$. All animals in the group treated with diazepam exhibited seizures, but only $70 \%$ in the group treated with the homeopathic remedy. Symptoms were violent in the control group and death appeared 240-600 seconds after intoxication; survival time was longer $(p<0.0005)$ in the group treated with diazepam and longest $(\mathrm{p}<0.0001)$ in the group treated with $N u x$ vomica $7 \mathrm{cH} .100 \%$ of animals in the control and diazepam treated groups died, whereas in the group treated with $\mathrm{Nux}$ vomica $7 \mathrm{cH}$ only $80 \%$ died $(\mathrm{p}=0.11)$. 


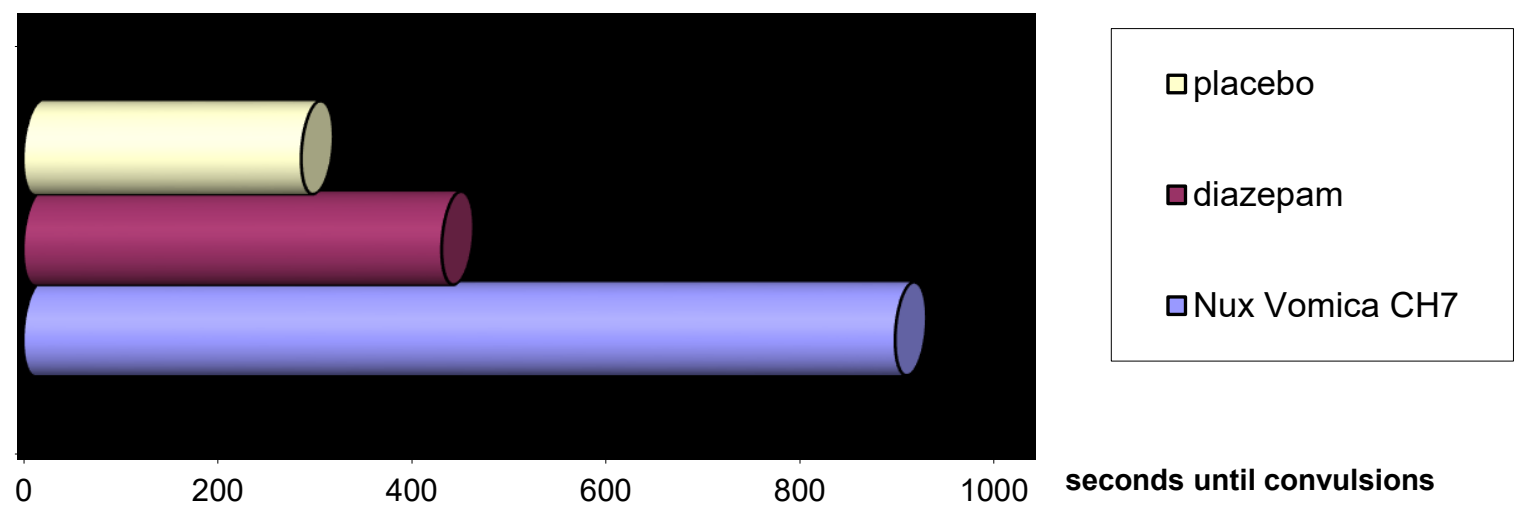

Figure 13 - The time passed until the occurrence of convulsions.

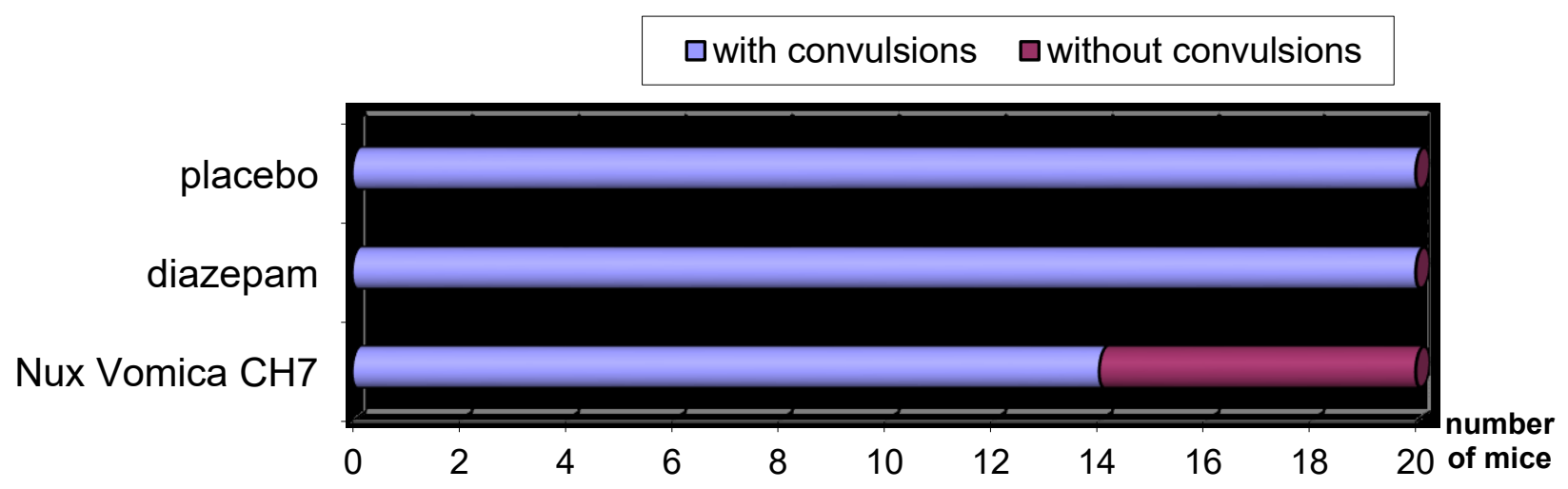

Figure 14 - Percentage of mice which presented convulsions
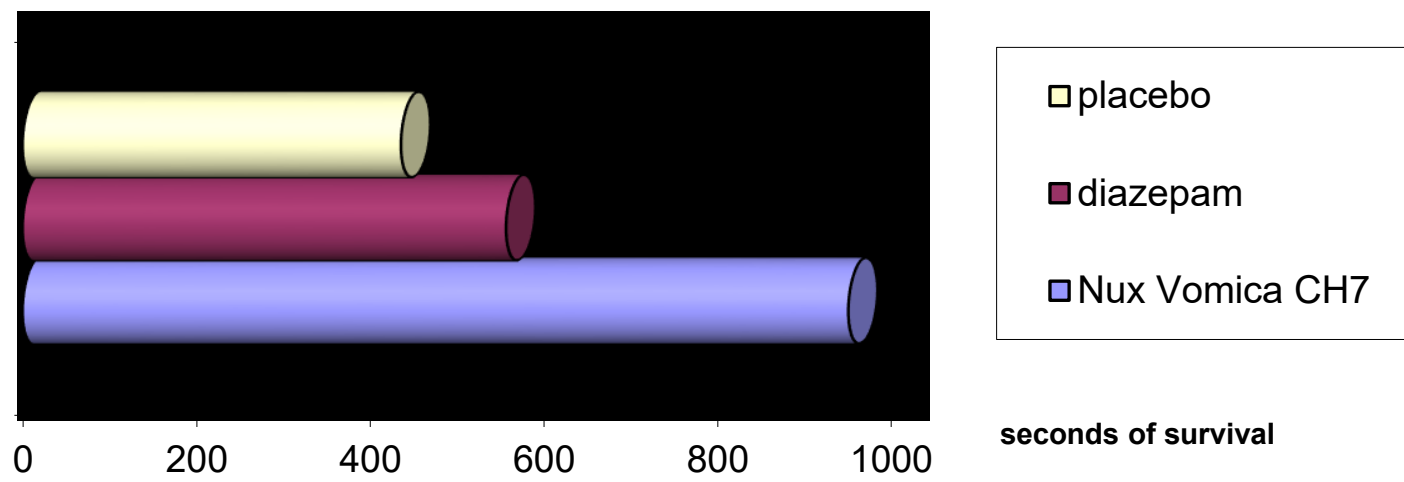

seconds of survival

Figure 15 - The time passed until the death of the mice 


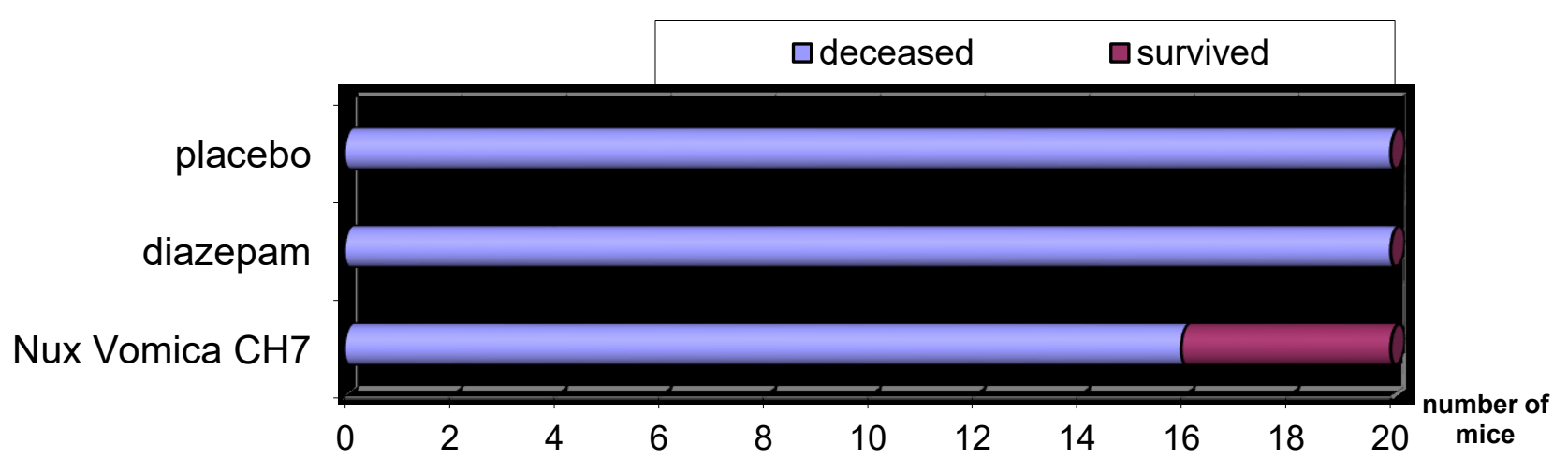

Figure 16 - The number of deceased and survived mice in each group

\section{Discussion}

Our overall experience shows that it is not difficult to carry out experimental studies assaying homeopathic medicines in randomized placebo-controlled tests returning statistically analyzable results. These experiments are simple to perform and if massively carried out in different centers around the world, there would be unquestionable evidence of the effects of different homeopathic remedies in different clinical conditions.

The basic requirement for this purpose is to select validated experimental models. The simplest and most reliable ones are the ones arising from common daily clinical practice or those taken from classical pharmacological studies modified as to fit the goals of a homeopathic assay.

For instance, one of our studies derived from a classic text described in the guide of practical pharmacology used by students of medicine [10]. This study aims to demonstrate the stimulation of salivation in mice through the use of pilocarpine by comparison with a group previously treated with atropine; in the latter, the secondary intake of pilocarpine elicits no salivation. This experiment serves to teach to students the properties of the muscarinic receptor.

To modify this test in a homeopathic manner, we added a supplementary step in the classic experimental, consisting in the administration of Belladona $7 \mathrm{cH}$ p.o. immediately after the injection of atropine, followed by the injection of pilocarpine. The results will be the subject of a separate article, but the results strongly indicated that pilocarpine-stimulated salivation reappears with the use of Belladona $7 \mathrm{cH}$.

Another experimental model we took from the pharmacology textbook is the one testing the anti-swelling properties of SAIDs and NSAIDs on formaldehyde-induced dorsoplantar edema. In this case, the additional step consisted in the addition of further experimental groups that received homeopathic medicine Apis mellifica $7 \mathrm{cH}$ and $15 \mathrm{cH}$ - below and above Avogadro's number, respectively, a combination Apis mellifica + diclofenac and another Apis mellifica + hydrocortisone hemisuccinate. A further twist included the solution of Apis mellifica in mint infusion to verify the homeopathic widespread idea that strong flavors and odors interfere with the effects of homeopathic medicines. The results showed a remarkable effect of Apis mellifica on the reduction of inflammation, which was present even when combined with hydrocortisone or taken in mint infusion. 
In this way, our experience supplies reliable experimental models to test not only the effects of homeopathic medicines but to establish different aspects of homeopathic theory and common clinical practice.

The main shortcoming in our design is that tests were not double-blind, a feature that we intended to include in our future experiments in order to eliminate residual biases.

\section{References}

[1] Nuhn T, Lüdtke R, Geraedts M. Placebo effect sizes in homeopathic compared to conventional drugs: a systematic review of randomized controlled trials. Homeopathy 2010; 99(1):76-82.

[2] Ernst E. Homeopathy, a "helpful placebo" or an unethical intervention? Trends Pharmacol Sci 2010; 31(1):1.

[3] European Convention for the Protection of Vertebrate Animals used for Experimental and Other Scientific Purposes, Strasbourg, 18.III.1986. Available from: http://conventions.coe.int/Treaty/en/Treaties/Html/123.htm

[4] Alecu A, Alecu M, Brezeanu R, Cojocaru A. Effect of the homeopathic remedy Arnica montana 7cH on mechanical trauma in mice. Cultura Homeopática. 2007; 20:16-18.

[5] Alecu A, Alecu M, Brezeanu R. Studiu al efectului antiinflamator al remediului homeopatic Apis comparativ cu alte medicamente cu efect antiinflamator. Revista Română de Homeopatie. 2004; 21:16-17. [Romanian].

[6] Alecu A, Alecu M, Brezeanu R, Mărcuş G, Cojocaru A. Răspunsul şobolanilor de laborator la tratament homeopatic după arsuri de gradul I. Medicina alternativă, fiziologie clinică şi metode de tratament 2008, 13:36-40. [Moldavian].

[7] Alecu A, Alecu M, Mărcuş G, Brezeanu R, Cojocaru A. Effect of the homeopathic remedies Arnica montana and Staphisagria on the time of healing of surgical wounds. Cultura Homeopática. 2007; 20:19-21.

[8] Alecu A, Cojocaru A, Alecu M, Brezeanu R. Remediul homeopatic Belladonna compensează blocajul receptorilor muscarinici provocat de atropină la animale de experiență. Revista Română de Homeopatie. 2007; 29:27-31. [Romanian].

[9] Alecu A, Brezeanu R, Cojocaru A, Alecu M, Cucuieț S, Monea M. Cercetări experimentale privind combaterea manifestarilor intoxicației cu stricnină prin tratament comparativ homeopatic şi alopatic. Revista Română de Homeopatie. 2006; 27-8, 52. [Romanian].

[10] Monea M, Cucuiet S, Doczi Z, Miklosik I, Suciu R. Îndrumător de lucrări practice de farmacologie, TârguMureş, 2006 [Romanian]. 


\section{RESUMO}

Este artigo discute a série de experimentos em modelos animais realizada por nosso grupo para avaliar o efeito de preparações homeopáticas escolhidas de acordo com o critério tradicional de similitude patogenêtica. Nossa experiência global indica que não é difícil realizar estudos experimentais com medicamentos homeopáticos em ensaios randomizados controlados com placebo que forneçam resultados analisáveis estatisticamente. O requisito básico para este propósito é escolher modelos experimentais validados. Os mais simples e mais confiáveis são aqueles derivados da prática clínica cotidiana assim como aqueles tomados de estudos farmacológicos clássicos modificados de modo a se corresponderem com os objetivos de um experimento homeopático. Procedendo desse modo, será possível construir um corpo sólido de evidência a favor dos efeitos biológicos das altas diluições.

Palavras chave: altas diluições; modelos experimentais; similitude patogenêtica; controle com placebo; significância estatística

\section{Diseños para investigación de altas diluciones en modelos animales: actualización}

\section{RESUMEN}

Este artículo discute la serie de experimentos en modelos animales realizada por nuestro grupo, con el propósito de evaluar el efecto de preparados homeopáticos elegidos según el criterio tradicional de similitud patogenética. Nuestra experiencia global indica que no es difícil llevar a cabo estudios experimentales con medicamentos homeopáticos en ensayos randomizados controlados con placebo que resulten en datos pasibles de análisis estadística. El requisito fundamental para este fin es elegir modelos experimentales validados. Los más simples y confiables son aquellos derivados de la praxis clínica cotidiana así como los tomados de estudios farmacológicos clásicos, modificados para cumplir los objetivos de un experimento homeopático. Actuando de esta manera, será posible construir un corpus sólido de evidencia favorable a los efectos biológicos de las altas diluciones.

Palabras llave: altas diluciones; modelos experimentales; similitud patogenética; control con placebo; significado estadístico

\section{(c)) BY-NC-ND Licensed to GIRI}

Support: authors declare that this study received no funding

Conflict of interest: authors declare there is no conflict of interest

Received: 07 February 2010; Revised: 20 March 2010; Published: 31 March 2010.

Correspondence author: Adrian Alecu, doctoralecu@yahoo.com

How to cite this article: Alecu A, Alecu M, Brezeanu R, Mărcuș G, Cojocaru A. Designs for research of high dilutions in animal models: an update. Int J High Dilution Res [online]. 2010 [cited YYYY Month dd]; 9(30): 5-15. Available from: http://www.feg.unesp.br/ ojs/index.php/ijhdr/article/view/379/414 